\title{
A comparison of nutrient losses to waters following pasture renewal by cultivation or direct-drilling
}

\author{
L.C. SMITH ${ }^{1}$, R.W. McDOWELL ${ }^{2}$ and G.P. COSGROVE ${ }^{3}$ \\ ${ }^{1}$ AgResearch, Woodlands Research Station, RD 1, Invercargill, New Zealand \\ ${ }^{2}$ AgResearch Invermay Private Bag 50034, Mosgiel, New Zealand \\ ${ }^{3}$ AgResearch Grasslands, Tennant Drive, Private Bag 11008, Palmerston North, New Zealand \\ chris.smith@agresearch.co.nz
}

\begin{abstract}
Agricultural soils enriched in phosphorus (P) have been linked to increases in $\mathrm{P}$ losses and declining water quality. Cultivation of pastures near sensitive waterways lowers surface soil $\mathrm{P}$ and therefore the concentration of $\mathrm{P}$ in surface runoff. However, such a practise can increase the mineralisation of organic nitrogen $(\mathrm{N})$, negating this as a mitigation option for $\mathrm{N}$ sensitive catchments. A field trial was set up to compare pasture renewal using either direct-drilling or cultivation (which mixed the plough layer to $150 \mathrm{~mm}$ ) on hydraulically-isolated runoff plots at Tussock Creek near Invercargill, Southland. The trial ran from March to December 2015. Soil P concentrations $(0-150 \mathrm{~mm}$ depth) decreased in the cultivated plots by about $20 \%, 8$ months after cultivation. Concentrations of nitrate- $\mathrm{N}$ in surface runoff and shallow drainage, and $\mathrm{P}$ in shallow drainage only, were not different between directdrilling and cultivation treatments. Cultivation reduced filterable reactive $\mathrm{P}$ (FRP) losses in surface runoff by $69 \%(\mathrm{P}=0.047)$ compared to direct-drilled plots. This study showed that mixing $\mathrm{P}$ within the plough layer decreased P loss over the 10 months of measurement. Conventional tillage that inverts the plough layer may result in even larger decreases in soil P concentrations. Tillage can therefore be used as a strategy to decrease $\mathrm{P}$ loss in small areas where surface runoff is likely, with little risk of increasing catchment-scale $\mathrm{N}$ loss. This includes near stream areas, but care must be taken to leave an adequate buffer strip to prevent sediment (and P) loss via erosion of bare soil.
\end{abstract}

Keywords: phosphorus-enriched soil, cultivation, direct-drilling, runoff, drainage

\section{Introduction}

Increasingly, the intensification of farming in New Zealand has resulted in land traditionally used to farm sheep being converted to dairy farming. This change in land use has seen an increase in soil P status, which has been linked to increases in P losses and declining water quality (Hamill \& McBride 2003). McDowell et al. (2003) showed that losses of filterable reactive P (FRP) increased as the Olsen $\mathrm{P}$ concentration increased and suggested that Olsen $\mathrm{P}$ concentrations be kept as close as possible to the agronomic optimum. Where the Olsen P concentration increased to above the agronomic optimum, options to limit, or reduce, the Olsen P concentration of soils quickly are few, as limiting or stopping P fertiliser application can potentially decrease pasture and animal performance.

One mitigation option that has shown promise in lowering soil Olsen $\mathrm{P}$ is the cultivation of pastures near sensitive waterways. This distributes P-rich topsoil throughout the plough layer, lowering the concentration of $\mathrm{P}$ at the soil surface and in surface runoff (hereafter called runoff: McDowell et al. 2010; Dodd et al. 2014). However, despite this, the presence of bare ground immediately following the cultivation can result in increased P loss via particulate P in runoff (Butler \& Haygarth 2007; Lucci et al. 2010). The use of directdrilling instead of cultivation has been shown to limit particulate $\mathrm{P}$ loss in runoff for cropping situations (Soane et al. 2012). It has, however, also resulted in increased losses of dissolved P (Ulen et al. 2010).

Cultivation can increase the mineralisation of soil organic nitrogen $(\mathrm{N})$ (Whitemore et al. 1992). Indeed, Fraser (1995) showed that ploughing of leguminous pastures, even in early autumn, can result in the accumulation of considerable mineral $\mathrm{N}$ in the soil profile. However, the use of direct-drilling can result in similar $\mathrm{N}$ leaching losses to those from cultivation (Fraser et al. 2013). The potential losses of $\mathrm{N}$ in drainage water could offset the benefits of the $\mathrm{P}$ mitigation option in $\mathrm{N}$-sensitive catchments. While the rapid establishment of arable crops to soak up such excess mineral $\mathrm{N}$ has been shown to limit $\mathrm{N}$ leaching losses over the winter drainage period (Fraser et al. 2013), the effectiveness of establishing permanent pasture for such a purpose has not been tested.

It was hypothesised that renewing pasture via cultivation - resulting in decreased Olsen $\mathrm{P}$ in the plough layer/topsoil - would decrease P losses in in runoff and drainage, but not increase $\mathrm{N}$ losses.

\section{Methods}

\section{Site and trial design}

The trial was situated on a Pukemutu (Argillic-fragic Perch-gley Pallic) soil (Carrick et al. 2000) on a dairy 
farm at Tussock Creek, $20 \mathrm{~km}$ north of Invercargill, Southland, New Zealand $\left(46^{\circ} 15^{\prime} \mathrm{S}\right.$; $\left.168^{\circ} 25^{\prime} \mathrm{E}\right)$. The soil was characterised by a fragipan at $30-90 \mathrm{~cm}$ depth and was naturally poorly drained, with low permeability in the subsoil and limited aeration during prolonged wet periods. The pasture was predominantly ryegrass/white clover that had been sown some 20-25 years previously.

Plots were installed at the site in November 2011 on slopes between 1 and $2 \%$. Plots were hydraulically isolated from the paddock and neighbouring plots by inserting $25 \times 150 \mathrm{~mm}$ boards $100 \mathrm{~mm}$ into the soil on the boundaries of each plot, allowing $50 \mathrm{~mm}$ to extend above the soil surface to direct runoff. The down-slope end of the plot formed a V $\left(140^{\circ}\right)$ with a metal frame complete with a pipe at the centre to direct runoff into a collection system which held 100 litres. Plot size was $10.2 \mathrm{~m}^{2}$ with 6 replicates. The layout and size of the plots prevented the use of the normal mole and tile drainage method of measuring drainage losses at this site (Monaghan et al. 2016). Drainage samples were, therefore, collected via four teflon cups inserted into each plot to a depth of $30-35 \mathrm{~cm}$ (i.e. just above the impermeable fragipan). While the cups were installed shallower than normal for this method of drainage collection, the presence of a fragipan prevented deeper installation. It is recognised that in this soil, the presence of preferential flow pathways will prevent efficient capture of vertical drainage using porous cup samplers (Wang et al. 2012). However, the fragipan also causes water to pond and mix above it - potentially improving capture by the cups. It may also lead to the underestimation of $\mathrm{N}$ losses via anaerobic conditions and denitrification. The Teflon cups were installed on 27 March 2015, 8 days following the cultivation/directdrilling of the treatments.

Plots were sprayed with Roundup (Lion) + Pulse penetrant at recommended rates on $3^{\text {rd }}$ March and again on $11^{\text {th }}$ March 2015 to remove the resident herbage. The cultivated plots were rotary-hoed to $150 \mathrm{~mm}$ depth and pasture hand-sown (seed broadcast then the plots lightly raked), on 19 March 2015. Direct drilled-plots also were sown on 19 March 2015 by forming slits (10-12 mm depth) with spades (to simulate a disc drill) and hand-sowing the pasture mix into the slits. These slits were spaced ca. $150 \mathrm{~mm}$ apart and were positioned across the slope of the plots. The pasture mix consisted of Prospect perennial ryegrass $(20 \mathrm{~kg})$ and Kopu II white clover $(5 \mathrm{~kg})$ sown at a rate of $20 \mathrm{~kg} / \mathrm{ha}$. Runoff and drainage measurements commenced in late April 2015 and pasture production measurements in August of the same year.

\section{Measurements}

Profile soil samples $(0-75,75-150$ and $150-300 \mathrm{~mm}$ depth) were collected before treatment in November
2014, March 2015 and December 2015 and analysed for Olsen P and water soluble P (WSP) concentrations. As the plots were fenced to exclude stock, pasture production was measured by a rising plate meter (Farmworks Precision Farming Systems Ltd., Fielding NZ) using the standard DairyNZ all seasons equation (kg DM = height x $140+500$; DairyNZ 2008) before the herbage was trimmed off by a rotary mower and clippings discarded.

A daily soil water balance model was used to determine total daily surplus water volumes and soil water deficit values at the site. The conceptual structure of this balance is described by Monaghan et al. (2009). Based upon observed drain flows and soil moisture measurements, it was assumed that the ratio of actual evapotranspiration to potential evapotranspiration had a value of 1.0 when soil moisture was between field capacity and a limiting soil water deficit of $50 \%$ of plant available water. Thereafter, this ratio decreased linearly to become zero at the permanent wilting point. Potential evapotranspiration data were obtained from the Invercargill meteorological station ca. $20 \mathrm{~km}$ south of the study site. Rainfall inputs were measured at the site by a $0.1 \mathrm{~mm}$ tipping bucket rain gauge linked to a Campbell Scientific CR10 data-logger. This rain gauge was monitored via telemetry to allow timely decisions on runoff and drainage collection to be made.

The runoff collection system was checked following rainfall $(>15 \mathrm{~mm})$ over 12 hours, and samples were collected if runoff had occurred. Due to runoff usually being generated by excess soil saturation, suction was applied to the Teflon cups to obtain drainage samples, at the same time runoff was collected. This did not occur for the first and last runoff events, which resulted from infiltration-excess conditions rather than soil saturation-excess.

Concentrations of total solids (TS) in runoff samples were determined gravimetrically after a known volume of sample had been evaporated to dryness in an oven set at $105^{\circ} \mathrm{C}$. All samples were stored frozen until analysed colorimetrically for filterable reactive phosphate (FRP), total filtered phosphate (TFP), total P (TP, runoff samples only), nitrate-N $\left(\mathrm{NO}_{3}-\mathrm{N}\right)$ and ammonium-N $\left(\mathrm{NH}_{4}-\mathrm{N}\right)$. Particulate $\mathrm{P}(\mathrm{PP})$ for the runoff samples was determined as TP less TFP. Before analysis by ANOVA using GENSTAT v17, all data were tested for normality and $\log _{10}$ transformed if necessary.

\section{Results and Discussion \\ Rainfall, runoff and drainage volumes}

Rainfall for the year was $1053 \mathrm{~mm}$, with $776 \mathrm{~mm}$ of this occurring between 19 March when the treatments were imposed and 30 November when measurements ceased. During this period the water balance model indicated there was $380 \mathrm{~mm}$ of surplus water. There 


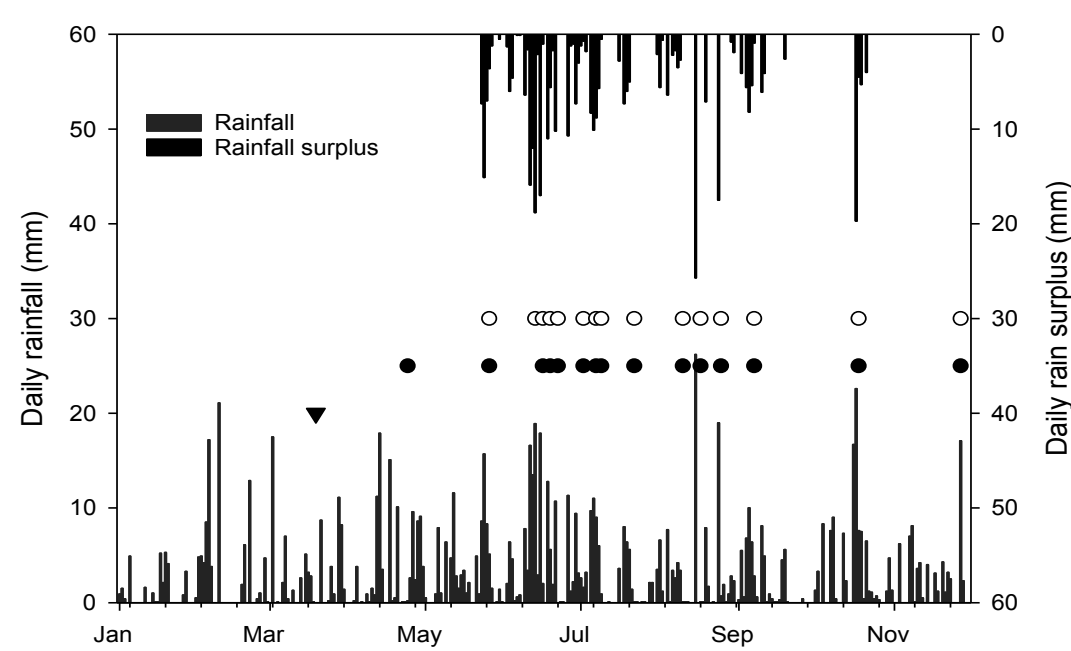

Figure 1 Daily and surplus rainfall at the Tussock Creek trial site. The timing of cultivation/ direct-drilling is shown as $\boldsymbol{\nabla}$, while $\bullet$ indicates the timing of runoff and $\mathrm{O}$ drainage events.

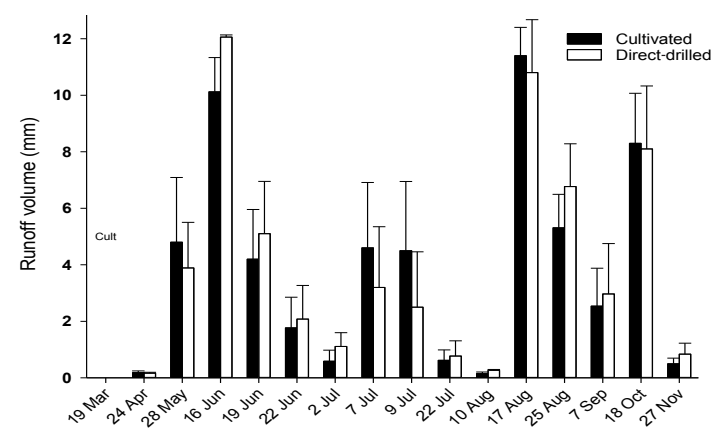

Figure 2 Runoff volumes measured at the Tussock Creek trial site. Bars indicate standard error of the mean $(n=6)$.

were 15 runoff and drainage events (Figure 1), with only the first and last runoff events not coinciding with surplus rainfall. There was $58 \mathrm{~mm}$ of runoff measured from the cultivated treatments and $61 \mathrm{~mm}$ from the direct-drilled treatment. This equates to $16 \%$ of the excess rainfall from the water balance model, a figure which compares favourably with previous work at this site that showed runoff accounted for $19 \%$ of surplus rainfall (Monaghan et al. 2016). The pattern of runoff indicated that 7 of the 15 runoff events exceeded $4 \mathrm{~mm}$ per event, with two of these exceeding $10 \mathrm{~mm}$ (Figure 2 ). In total, these seven larger events accounted for $85 \%$ of the total runoff.

\section{Pasture production}

There were three spring pasture growth measurements (Table 1) with the cultivated treatment producing $15 \%$ more pasture than the direct-drilled treatment $(\mathrm{P}<0.001)$. This difference was more pronounced at the September harvest (21\%) than the November and December harvests (9\%). Dodd et al. (2014) found increased pasture production following tillage on a similar soil (Mottled Fragic Pallic) to that studied here (Argillic-fragic Perchgley Pallic).

\section{Soil analysis}

Initial soil sample results, collected in November 2014, were used to randomise the treatments. However, by March when the cultivation occurred, the Olsen $\mathrm{P}$ concentration in the topsoil $(0-75 \mathrm{~mm})$ had changed, so that the concentrations in the direct-drilled plots were less than those in the cultivated plots (Table 2; $\mathrm{P}=0.018$ ). While there were no initial differences in the soil WSP concentrations between treatments, concentrations decreased $(\mathrm{P}<0.001)$ with depth.

The cultivation method used in this study (rotaryhoeing) did not significantly decrease either Olsen P or WSP concentration for the $0-75 \mathrm{~mm}$ soil layer (Table 2; December results). This is in contrast with other studies (e.g. McDowell et al. 2010), where topsoil $\mathrm{P}$ was significantly lowered by cultivation. However, McDowell et al. (2010) employed conventional inversion tillage, which would have buried the original P-rich topsoil below $75 \mathrm{~mm}$ depth. The cultivation in this study did, however, result in a significant lowering of Olsen $\mathrm{P}$ concentrations for the total depth of cultivation $(0-150 \mathrm{~mm})$, from $32 \mu \mathrm{g} / \mathrm{mL}$ for the direct-drilled treatment to $26 \mu \mathrm{g} / \mathrm{mL}$ for the cultivated treatment $(\mathrm{P}=0.03)$. Thus, it would appear that cultivation method and depth are important factors when trying to alter topsoil P concentration.

Table 1 Pasture production for three harvests from sowing to the end of spring 2015 ( $\mathrm{kg} \mathrm{DM} / \mathrm{ha})$. The standard error of difference (SED) is given along with the F-statistic for treatment comparison (bold if significant).

\begin{tabular}{|c|c|c|c|c|}
\hline Treatment & 30 Sept $^{1}$ & $4 \mathrm{Nov}$ & $17 \mathrm{Dec}$ & Total \\
\hline Cultivated & 2450 & 2840 & 3440 & 5690 \\
\hline Direct-drilled & 2030 & 2600 & 3160 & 4940 \\
\hline SED & 86 & 86 & 109 & 93 \\
\hline F-statistic & 0.004 & 0.040 & 0.049 & $<0.001$ \\
\hline
\end{tabular}

1accumulated since the pasture was sown on 19 March 2015. 


\section{Nutrient concentrations and losses in runoff and shallow drainage}

When compared to direct-drilling, mixing the plough layer with a rotary hoe resulted in significantly lower FRP concentrations in runoff for 6 of the 15 runoff events (Figure 3). These differences between treatments were mirrored by both TFP and TP concentrations for the same runoff events. However, there were no treatment effects on FRP, TFP or TP concentrations in shallow drainage. Considering that the six significant events accounted for $77 \%$ of the total runoff volumes (Figure 2 ), it was not surprising that cultivation resulted in $39 \%$ lower FRP losses ( $\mathrm{P}=0.047)$ and $49 \%$ lower TP losses (NS; Table 3) than the direct-drilled treatment. This result is in line with previous work, albeit in a cropping situation, which showed lower FRP losses with normal cultivation compared to direct-drilling (Ulen et al. 2010). Particulate $P$ losses from the cultivated plots were not significantly different to those measured from the direct-drilled plots.

Nitrogen concentrations and losses in both runoff and shallow drainage were not increased by cultivation compared to direct-drilling (Figure 4; Table 3). In a study of four soil types, Dodd et al. (2014) suggested that the mineralisation effect following cultivation was likely to be short-lived, and that soil type had a large impact on the amounts of $\mathrm{N}$ leached, with the Pallic soil leaching the least amount of $\mathrm{N}$. Considering that there were 36 days between cultivation and the first runoff event, albeit a small one $(0.2 \mathrm{~mm})$, and 70 days before any runoff event of note $(>3.5 \mathrm{~mm})$, it is likely that the $\mathrm{N}$ mineralised by the cultivation had either been reimmobilised, used by the establishing pasture or lost to the atmosphere.

The loss of nutrients, particularly $\mathrm{P}$, via runoff was increased when bare ground was present (Lucci et al. 2010). Runoff events that occur in the period between cultivation and pasture establishment can result in increased P loss. Butler \& Haygarth (2007) suggested that rainfall intensity, and consequently size of the runoff events before the pasture sward had developed, greatly influenced $\mathrm{P}$ loss pathways. Thus, cultivation should be timed to minimise the time the soil is left bare and when runoff events are unlikely.

\section{Conclusions and recommendations}

Mixing topsoil via rotary hoe decreased FRP and TP fluxes in runoff by 69 and 49\%, respectively, compared

Table 2 Pre- and post-treatment soil Olsen P and water soluble P concentrations $(\mu \mathrm{g} / \mathrm{mL})$ results. The standard error of difference (SED) is given along with the F-statistic for treatment comparison (bold if significant).

\begin{tabular}{|c|c|c|c|c|c|c|}
\hline \multirow[t]{2}{*}{ Treatment } & \multicolumn{2}{|c|}{$\begin{array}{c}\text { Nov } 2014 \\
120 \text { days pre }\end{array}$} & \multicolumn{2}{|c|}{$\begin{array}{l}\text { March } 2015 \\
14 \text { days pre }\end{array}$} & \multicolumn{2}{|c|}{$\begin{array}{l}\text { December } 2015 \\
200 \text { days post }\end{array}$} \\
\hline & Olsen P & WSP & Olsen P & WSP & Olsen P & WSP \\
\hline \multicolumn{7}{|l|}{$0-75 \mathrm{~mm}$} \\
\hline Cultivated & 43 & 0.091 & 37 & 0.101 & 37 & 0.047 \\
\hline Direct-drilled & 43 & 0.086 & 34 & 0.094 & 47 & 0.055 \\
\hline SED & 3.3 & 0.010 & 0.9 & 0.010 & 4.9 & 0.015 \\
\hline F-statistic & 0.917 & 0.637 & 0.018 & 0.517 & 0.104 & 0.604 \\
\hline \multicolumn{7}{|l|}{$75-150 \mathrm{~mm}$} \\
\hline Cultivated & $\mathrm{ND}^{1}$ & 0.035 & ND & ND & 15 & 0.025 \\
\hline Direct-drilled & & 0.037 & & & 17 & 0.029 \\
\hline SED & & 0.002 & & & 2.1 & 0.004 \\
\hline F-statistic & & 0.758 & & & 0.255 & 0.425 \\
\hline \multicolumn{7}{|l|}{$150-300 \mathrm{~mm}$} \\
\hline Cultivated & ND & 0.023 & ND & ND & 4 & 0.014 \\
\hline Direct-drilled & & 0.025 & & & 5 & 0.016 \\
\hline SED & & 0.002 & & & 0.4 & 0.001 \\
\hline F-statistic & & 0.201 & & & 0.487 & 0.141 \\
\hline F-statistic (depth) & & $<0.001$ & & & $<0.001$ & $<0.001$ \\
\hline
\end{tabular}

${ }^{1} \mathrm{ND}=$ not determined 

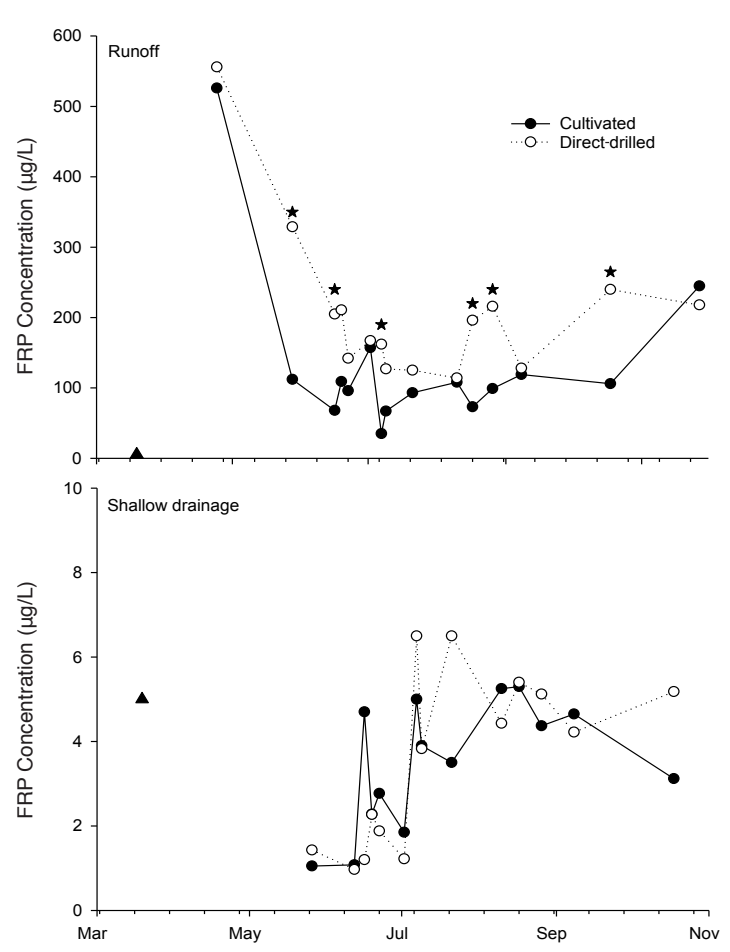

Figure 3 The effect of cultivation and direct-drilling on filterable reactive $\mathrm{P}$ (FRP) concentrations in runoff and shallow drainage. Time of cultivation/directdrilling is given by $\boldsymbol{\Delta}$, while the stars indicate significant differences between treatments $(\mathrm{P}<0.05)$.

to direct-drilling. There was no significant increase in $\mathrm{N}$ fluxes via runoff or $\mathrm{N}$ and $\mathrm{P}$ fluxes in shallow drainage, as a result of cultivation. Conventional tillage that inverts the plough layer may result in greater decreases in soil P concentrations and hence P losses in runoff.
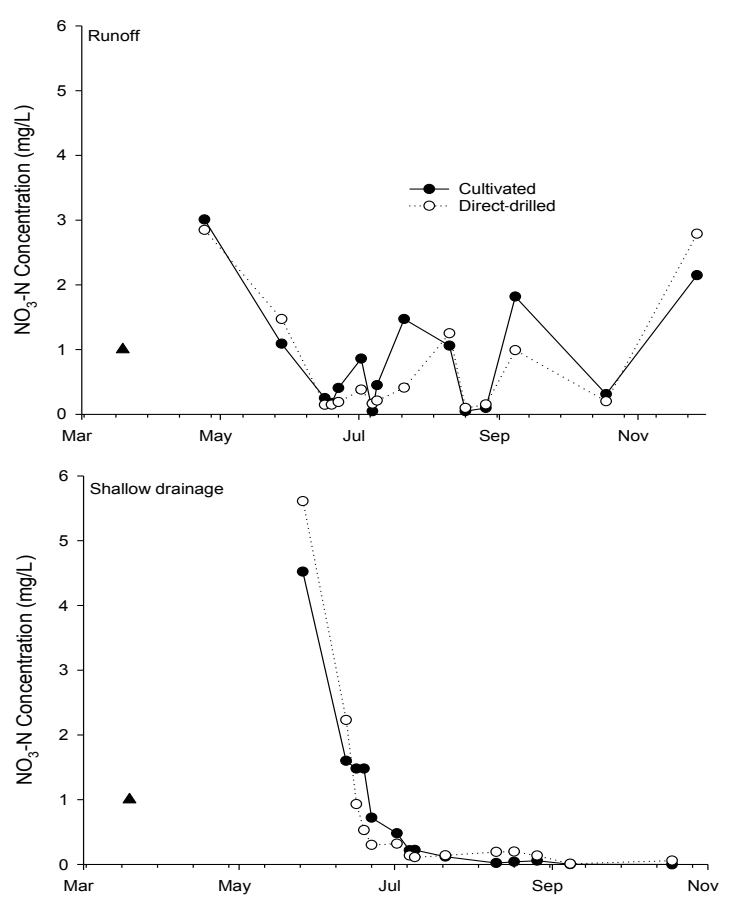

Figure 4 The effect of cultivation and direct-drilling on nitrate-N $\left(\mathrm{NO}_{3}-\mathrm{N}\right)$ concentrations in runoff and shallow drainage. Time of cultivation/direct-drilling is given by

$\Delta$.

Tillage is therefore recommended as a possible strategy to decrease P losses in areas where runoff is likely. This could occur in near-stream areas where runoff is produced or flows through before entering a stream. However, tillage of near-stream areas should leave a buffer strip to avoid erosion of soil (and associated P) while bare. If tillage is limited to such small areas, it is unlikely to result in increased $\mathrm{N}$ losses to water.

Table 3 Mean loads of total solids (TS), particulate $P(P P)$, filterable reactive $P(F R P)$, total dissolved $P$ (TDP), total $P$ (TP), nitrate- $\mathrm{N}\left(\mathrm{NO}_{3}-\mathrm{N}\right)$ and ammonium- $\mathrm{N}\left(\mathrm{NH}_{4}-\mathrm{N}\right)$ in runoff and shallow drainage for 8 months post-treatment. The F-statistic for treatment comparison is presented (bold if significant).

\begin{tabular}{|c|c|c|c|c|c|c|c|}
\hline Treatment & TS (kg/ha) & PP (g/ha) & FRP (g/ha) & TDP (g/ha) & TP (g/ha) & $\mathrm{NO}_{3}-\mathrm{N}(\mathrm{kg} / \mathrm{ha})$ & $\mathrm{NH}_{4}-\mathrm{N}(\mathrm{kg} / \mathrm{ha})$ \\
\hline \multicolumn{8}{|l|}{ Runoff } \\
\hline Cultivated & 106 & 93 & 42 & 56 & 149 & 0.144 & 0.403 \\
\hline Direct-drilled & 105 & 140 & 136 & 152 & 292 & 0.160 & 0.601 \\
\hline F-statistic & 0.768 & 0.253 & 0.047 & 0.080 & 0.147 & 0.269 & 0.189 \\
\hline \multicolumn{8}{|c|}{ Shallow drainage } \\
\hline Cultivated & $\mathrm{ND}^{1}$ & ND & 12 & 29 & ND & 3.46 & 0.54 \\
\hline Direct-drilled & & & 15 & 39 & & 3.77 & 0.59 \\
\hline F-statistic & & & 0.247 & 0.119 & & 0.334 & 0.227 \\
\hline
\end{tabular}

${ }^{1} \mathrm{ND}=$ Not determined 


\section{ACKNOWLEDGEMENTS}

We thank Tom Orchiston and Wayne Worth for assistance with the cultivations as well as Martin Kear and Stuart Lindsey for sample analysis. This research was funded by the Pastoral 21 II Consortium, a collaborative venture between DairyNZ, Fonterra, Dairy Companies Association of New Zealand, Beef + Lamb New Zealand and the Ministry of Business, Innovation and Employment, as well as the latter's Clean Water, Productive Land Programme (C10CX1006).

\section{REFERENCES}

Butler, P.J.; Haygarth, P.M. 2007. Effects of tillage and reseeding on phosphorus transfers from grassland. Soil Use and Management 23: 71-81.

Carrick, S.T.; Taylor, A.L.; Risk, J.T. 2000. Soils of the Winton-Makarewa district. Scale 1:50000. Topoclimate South Soil Map 6a. Topoclimate South, Mataura, New Zealand.

DairyNZ 2008. Using the Rising Plate Meter. DairyNZ Farmfact: 1-15.

Dodd, R.J.; McDowell, R.W.; Condron, L.M. 2014. Is tillage an effective method to decrease phosphorus loss from phosphorus enriched pastoral soils. Soil and Tillage Research 135: 1-8.

Francis, G.S. 1995. Management practises for minimising nitrate leaching after ploughing temporary leguminous pastures in Canterbury, New Zealand. Journal of Contaminant Hydrology 20: 313-327.

Fraser, P.M.; Curtain, D.; Harrison-Kirk, T.; Meenken, M.H.; Beare, M.H.; Tabley, F.; Gillespie, R.N.; Francis, G.S. 2013. Winter nitrate leaching under different tillage and winter cover crop management practices. Soil Science Society of America Journal 77: 1391-1401.

Hamill, K.D.; McBride, G.B. 2003. River water quality trends and increased dairying in Southland., New Zealand. New Zealand Journal of Marine and Freshwater Research 37: 323-332.

Lucci, G.M.; McDowell, R.W.; Condron, L.M. 2010. Potential phosphorus and sediment loads from sources within a dairy farmed catchment. Soil Use and Management 26: 44-52.

McDowell, R.W.; Monaghan, R.M.; Morton, J. 2003. Soil phosphorus concentrations to minimize potential $\mathrm{P}$ loss to surface waters in southland. New Zealand Journal of Agricultural Research 46: 239-254.

McDowell, R.W.; Knowler, K.; Cosgrove, G.P. 2010. Establishment of a split grass-clover system to improve water quality and profitability. Proceedings of the New Zealand Grassland Association 72: 171176.

Monaghan, R.M.; Smith, L.C.; Ledgard, S.F. 2009. The effectiveness of a granular formulation of dicyandiamide (DCD) in limiting nitrate leaching from a grazed dairy pasture. New Zealand Journal of Agricultural Research 52: 145-159.

Monaghan, R.M.; Smith, L.C.; Muirhead, R.W. 2016. Pathways of contaminant transfers to water from an artificially-drained soil under intensive grazing by dairy cows. Agriculture Ecosystems and Environment 220: 76-88.

Soane, B.D.; Ball, B.C.; Arvidsson, J.; Basch, G.; Mereno, F.; Roger-Estrade, J. 2012. No-till in northern, western and south-western Europe: A review of problems and opportunities for crop production and the environment. Soil and Tillage Research 118: 66-87.

Ulen, B.; Aronsson, H.; Bechmenn, M.; Krogstad, T.; Oygarden, L.; Stenberg, M. 2010. Soil tillage methods to control phosphorus loss and potention side-effects: a Scandinavian review. Soil Use and Management 26: 94-107.

Wang, Q.; Cameron, K.; Buchan, G.; Zhao, L.; Zhang, E.H.; Smith, N.; Carrick. S. 2012. Comparison of lysimeters and porous ceramic cups for measuring nitrate leaching in different soil types. New Zealand Journal of Agricultural Research 55: 333-345.

Whitemore, A.P.; Bradley, N.J.; Johnson, P.A. 1992. The potential contribution of ploughed grassland to nitrate leaching. Agriculture Ecosystems and Environment 39: 229-233. 